\title{
The Effect of Using Vocabulary Journal Strategy on Students' Reading Comprehension at State Junior High School 1 Cerenti Kuantan Regency
}

\author{
Irma Juita \\ Universitas Islam Negeri Sultan Syarif Kasim Riau, Indonesia \\ Irmajuita29@yahoo.com
}

\begin{abstract}
This research was urged by the students' problem in reading narrative texts at State Junior High School 1 Cerenti Kuantan Singingi Regency. For example, some students still had the difficulties in finding out the main idea and analyzing the reading text. Thus, the writer was interested in carrying out this research based the problems above. The objective of this research was to find out whether there was or nor significant effect of using Vocabulary Journal strategy on students' reading comprehension at State Junior High School 1 Cerenti Kuantan Singingi Regency.The design of this research was a quasi experimental design. The population of this research was the eighth grade students of Junior High School 1 Cerenti Kuantan Singingi Regency in 2015-2016 academic years. The sample was taken by using cluster random sampling. The sample was VIII 1 as an experimental class, and VIII 2 as control class. Thus, the number of sample from two classes was 54 students. To analyze the data, the writer adopted independent sample T-test formula by using SPSS 16.0 version. After analyzing the data, the writer found the result of t-observe was $2.03<5.386>2.72$. Thus, the writer could conclude that there is a significant difference between the students taught by using and taught without using Vocabulary Journal strategy on students' reading comprehension in narrative text at State Junior High School 1 Cerenti Kuantan Singingi Regency.
\end{abstract}

\section{Key Words: Effect, Vocabulary Journal Strategy, Students' Reading comprehension}

\section{Introduction}

State Junior High School 1 Cerenti is one of the junior high school in Cerenti Kuantan Singingi regency. As a formal institution, this school also offers English subject to the students, especially in term reading skill. Similar to other schools in Indonesia, this school uses Character School Based
Curriculum (KTSP) as guidance in teaching and learning process. English has become a compulsory subject to be taught there. It is taught twice a week with duration 40 minutes for one lesson. The passing grade of English Course by this school is 75 . Reading is one of the skills that must be taught and learned by the students in the junior high school 1 Cerenti. In standard competence, 
students are required to understand the meaning of simple short essay in form of recount and narrative texts to interact with around environment. While in basic competence, students are required to respond to the meaning in the written text of simple short functional in form recount and narrative text.

Besides that, the writer found the students got difficulties in comprehending in reading narrative texts. When the writer did observation, she also interviewed the teacher by asking about students' problem and what learning strategies were used by the teacher in teaching reading. The teacher said that the students could read the text well, but the students were not able to comprehend reading text. One of the factors was the students had lack of vocabularies. Then, the teacher taught the students by using conventional strategy in teaching reading in which the teacher asked the students to read the text individually or in pairs. Then, the teacher asked the students to find out unfamiliar words or asked the students to translate word by word to get the information what the text talked about. Next, the teacher gave some questions related the detailed information in narrative text. Finally, the teacher concluded the lesson before closing. In fact, some of the students could not finish answering the questions related to reading text.

From the explanation above, it can be concluded that the students had problems in comprehending reading of narrative text. The discrepancy was seen from the students unable to read the English text well. Yet, the students did not have problem in reading. The problem was the students were not able to comprehend reading text. It clearly showed the discrepancy that if a reader could read the text, so a reader also should be able to comprehend the whole content of text. In fact, the student could not understand and get the whole content in reading text; even the students could read the text properly. Then, the students' scores in reading narrative texts showed that the students had problems in comprehension in reading narrative texts, and most of the students had low scores because they did not achieve the passing grade score in reading.

In accordance with the case above, the writer found the following symptoms as follows:

1. Some of the students were not able to identify the main idea of reading narrative text.

2. Some of the students were not able to know the meaning details of narrative text.

3. Some of the students were not able to identify the information of reading narrative text.

4. Some of the students were not able to identify generic structure of reading narrative text.

\section{The Theoretical Framework}

According to Syafii (2013:93), theoretical framework is viewed as the relevant theories related to references cited from various printed documentsbooks, articles, magazine, newspaper, research reports either published or unpublished, dictionary and the like as to seriously study the problem in dept and to provide both researcher and readers with the alternative answer of the problem theoretically.

\section{a) Definition of Vocabulary Journal}

According to June Preszler (1925: 24), vocabulary journal is Individual vocabulary notebooks that invite students to strengthen their understanding on meaning sentence in word 
and internalize meaning for use throughout their lives. Robert J.Marzano, in his book Building Academic Vocabulary: Teacher's Manual, suggests using tabs in the booklets to note different subjects or topics. Having a dictionary definition is insufficient according to Marzano. He explains that dictionary definitions are not written in conversational language. As a result, students are un able to internalize meaning.

Patrisia A. Antonacci, chaterine M. o' callaghan (2012: 110) stated that Vocabulary Journals are valuable in helping students explore or understand the meanings of words that they encounter while sentence in reading. These journals are a specific type of learning $\log$ where students record "their ideas and information from content areas in a notebook and responses about new words that they have learned from reading literature or textbooks. Journals are not notebooks used to record notes. Rather, Vocabulary Journals are used by students to respond and transact with words, concepts, and ideas through the use of their own language. Students select words from their readings that are difficult, novel, or used in different contexts. They use their journals to explore the words' meanings, make connections between the new words and their own experiences and ideas they already know, and produce rich definitions.

The primary purpose of using Vocabulary Journals is to encourage students to become word conscious by collecting new and interesting words and learning their meanings through engaged explorations. Vocabulary Journals may be used as part of guided reading lessons, during independent reading, and during their readings across the content areas. Teachers may use Vocabulary Journals effectively with students at all grade levels by adjusting their instructional procedures. For example, Bone (2000) used Vocabulary Journals with eighth-grade students in her literature class. She encouraged students to explore understanding and meanings of sentence words by using different graphic organizers in their journals. Students used graphics for making connections between word meanings, for building knowledge with concept ladders, and for working through the meanings of words with a K-WL chart.

\section{b) Procedures of Vocabulary Journal}

According to patrisia A. Antonacci, chaterine M. o' (2012: 111), the indicators of vocabulary journal strategy (variable $\mathrm{X}$ ) are as follows:

a. The teacher introduces Vocabulary Journals to students. Talk about the purpose of the journal and how to identify words from their sentence in readings to explore a word's meaning and use.

b. The teacher Demonstrates how to select words from a 
sentence reading Conduct a read-aloud to show the students which words might be selected for their Vocabulary Journals.

c. The teacher Uses a thinkaloud to model how to construct meanings from sentence words. Engage in a think-aloud on how to interact with text to construct and build word meaning. Demonstrate to students how to as :

1) Consult other resources such as glossaries and dictionaries to show meanings of words or search illustrations, diagrams, and subtitles;

2) Use the context of the sentence or sentences around the word to explore the meaning of the word;

3) Show word relationships such as synonyms, antonyms, homonyms, etc.; and

4) Explore meaning through making connections to the word, such as what they know that is similar to the meaning of the word or other readings in which the word might have been used.

d. Record ideas that have been used to explore the meaning of the word. Display different techniques that were used to represent word meanings and relationships. For example, discuss the use of word or concept maps and other graphic organizers to show word and concept relationships and the use of pictures to depict meanings.

e. The teacher encourages students' systematic use and sharing of Vocabulary Journals. Develop students' interest in words by encouraging their use of Vocabulary Journals and providing a range of contexts where students use their journals. They may be used most effectively in literature circles, guided reading, independent reading, shared reading, read-aloud, and reading across the curriculum. Teachers encourage the students' use of journals during discussions where they may share their words, ideas, and questions.

f. Next, the teacher Encourages students to use their Vocabulary Journals as a resource. Provide authentic ways to help students use their Vocabulary Journals as a tool for learning. Since journals are a storehouse for new and interesting words and their meanings, spellings of words, concepts, and ideas, students should be encouraged to use their Vocabulary Journals during writing.

c) Teaching Reading by Using Vocabulary Journal Strategy

Patrisia A. Antonacci, chaterine M. o' callaghan (2012: 111) stated that When to use the strategy: Vocabulary Journals may be used before, during, or after reading depending on how the teacher will use the journals. 
For example, oftentimes the teacher will use direct instruction for teaching the key words before reading the text. Students will then record the words and their initial ideas in their journals, but they will return to the words during and after reading to personalize the meanings of the words. During independent reading, students will use their journals during and after reading. Strategy modifications for grade levels: The Vocabulary Journal strategy may be used at all grade levels. For the primary grades, teachers will need to monitor students' use of the journals to a greater extent. Additionally, it may take time for first- and second- graders to identify words for their journals; therefore, teachers should suggest words for their journals and then encourage them to add a word or two

\section{The Data Presentation}

\section{Data Presentation of Students' Reading Comprehension Who being Taught by Using Vocabulary Journal Strategy}

The data of students' reading comprehension in narrative text taught by using vocabulary journal strategy were gotten from pre-test and posttest of VIII 1class as an experimental class. The data can be seen from the table below:

Table IV.1

Pre-test and Post-test Score of Experimental Class

\begin{tabular}{|c|l|c|c|c|c|}
\hline \multirow{2}{*}{ No. } & \multirow{2}{*}{ Students } & \multicolumn{3}{|c|}{ Experimenal Class } & \\
\cline { 3 - 6 } & & Pre-Test & Categories & Post-Test & Categories \\
\hline $\mathbf{1}$ & Student 1 & 75 & Good & 85 & Very \\
\hline $\mathbf{2}$ & Student 2 & 70 & Good & 80 & Very good \\
\hline $\mathbf{3}$ & Student 3 & 70 & Good & 85 & Very good \\
\hline $\mathbf{4}$ & Student 4 & 55 & Less & 60 & Enough \\
\hline $\mathbf{5}$ & Student 5 & 50 & Less & 70 & Good \\
\hline $\mathbf{6}$ & Student 6 & 65 & Enough & 70 & Good \\
\hline $\mathbf{7}$ & Student 7 & 75 & Good & 85 & Very Good \\
\hline $\mathbf{8}$ & Student 8 & 65 & Enough & 80 & Very Good \\
\hline $\mathbf{9}$ & Student 9 & 60 & Enough & 75 & Good \\
\hline $\mathbf{1 0}$ & Student 10 & 65 & Enough & 60 & Enough \\
\hline $\mathbf{1 1}$ & Student 11 & 85 & Very Good & 90 & Very good \\
\hline $\mathbf{1 2}$ & Student 12 & 60 & Enough & 90 & Very Good \\
\hline $\mathbf{1 3}$ & Student 13 & 70 & Good & 60 & Enough \\
\hline $\mathbf{1 4}$ & Student 14 & 55 & Less & 70 & Good \\
\hline $\mathbf{1 5}$ & Student 15 & 60 & Enough & 75 & Good \\
\hline $\mathbf{1 6}$ & Student 16 & 75 & Good & 85 & Very Good \\
\hline $\mathbf{1 7}$ & Student 17 & 55 & Less & 90 & Very Good \\
\hline $\mathbf{1 8}$ & Student 18 & 40 & Less & 60 & Enough \\
\hline $\mathbf{1 9}$ & Student 19 & 50 & Less & 75 & Good \\
\hline $\mathbf{2 0}$ & Student 20 & 55 & Less & 60 & Enough \\
\hline $\mathbf{2 1}$ & Student 21 & 50 & Less & 75 & Good \\
\hline $\mathbf{2 2}$ & Student 22 & 50 & Less & 75 & Good \\
\hline
\end{tabular}




\begin{tabular}{|l|l|c|c|c|c|}
$\mathbf{2 3}$ & Student 23 & 60 & Enough & 60 & Enough \\
\hline $\mathbf{2 4}$ & Student 24 & 75 & Good & 75 & Good \\
\hline $\mathbf{2 5}$ & Student 25 & 45 & Less & 75 & Good \\
\hline $\mathbf{2 6}$ & Student 26 & 80 & Very Good & 90 & Very good \\
\hline $\mathbf{2 7}$ & Student 27 & 65 & Enough & 80 & Very Good \\
\hline & Total & \multicolumn{2}{|c|}{$\mathbf{6 8 0}$} & \multicolumn{2}{c|}{$\mathbf{2 0 3 5}$} \\
\hline
\end{tabular}

a. Pre-Test Score of Experimental Class

Table IV.2

The Distribution of Frequency of Students' Pre-Test Scores of Experimental Class

\begin{tabular}{|c|c|c|c|c|c|}
\hline \multicolumn{6}{|c|}{ Pretestexp } \\
\hline & & Frequency & Percent & Valid Percent & $\begin{array}{l}\text { Cumulative } \\
\text { Percent }\end{array}$ \\
\hline \multirow[t]{11}{*}{ Valid } & 40 & 1 & 3.7 & 3.7 & 3.7 \\
\hline & 45 & 1 & 3.7 & 3.7 & 7.4 \\
\hline & 50 & 4 & 14.8 & 14.8 & 22.2 \\
\hline & 55 & 4 & 14.8 & 14.8 & 37.0 \\
\hline & 60 & 4 & 14.8 & 14.8 & 51.9 \\
\hline & 65 & 4 & 14.8 & 14.8 & 66.7 \\
\hline & 70 & 3 & 11.1 & 11.1 & 77.8 \\
\hline & 75 & 4 & 14.8 & 14.8 & 92.6 \\
\hline & 80 & 1 & 3.7 & 3.7 & 96.3 \\
\hline & 85 & 1 & 3.7 & 3.7 & 100.0 \\
\hline & Total & 27 & 100.0 & 100.0 & \\
\hline
\end{tabular}

\section{Referring to the table} above, the total number of students were 27 students. It showed that there was 1 student who got score $40 \quad(3.7 \%), 1$ student who got $45(3.7 \%), 4$ students who got $50(14.8 \%), 1$ student who got 45 (3.7), 4 students who got 50 (14.8\%), 4 students who got 55 (14.8\%), 4 students who got $60(14.8 \%), 4$ students who got $65(14.8 \%), 3$ students who got $70(11.1 \%), 4$ students who got $75(14.8 \%), 1$ student who got $80(3.7 \%)$, and 1 student who got $85(3.7 \%)$.

\section{b. Post-Test Score of Experimental Class}


Table IV.2

The Distribution of Frequency of Students' Post-Test Scores of Experimental Class

\begin{tabular}{|rl|r|r|r|r|}
\multicolumn{7}{|c|}{ Postexperiment } \\
\hline & & Frequency & Percent & Valid Percent & $\begin{array}{c}\text { Cumulative } \\
\text { Percent }\end{array}$ \\
\hline Valid & 60 & 6 & 22.2 & 22.2 & 22.2 \\
& 70 & 3 & 11.1 & 11.1 & 33.3 \\
& 75 & 25.9 & 25.9 & 59.3 \\
& 70 & 3 & 11.1 & 11.1 & 70.4 \\
& 85 & 4 & 14.8 & 14.8 & 85.2 \\
& & 14.8 & 14.8 & 100.0 \\
& Total & 27 & 100.0 & 100.0 & \\
\hline
\end{tabular}

Referring to the table above, the total number of students were 27 students. It shows that there were 6 students who got score $60(22.2 \%), 3$ students who got $70(11.1 \%), 7$ students who got $75(25.9 \%), 3$ students who got $80(11.1 \%), 4$ students who got 85 (14.8\%), and 4 student who got 90 $(14.8 \%)$.

Furthermore, the writer used the classification of students' score as well to analyze the students post-test score in experimental class described as follow:

Table IV. 3

The Classification of Students' Score

\begin{tabular}{|c|c|c|c|c|}
\hline $\mathrm{NO}$ & Score & Categories & Frequency & Percentage \\
\hline 1 & $80-100$ & Very good & 11 & $44 \%$ \\
\hline 2 & $66-79$ & Good & 10 & $40 \%$ \\
\hline 3 & $56-65$ & Enough & 6 & $16 \%$ \\
\hline 4 & $40-55$ & Less & - & - \\
\hline 5 & $30-39$ & Fail & - & - \\
\hline \multicolumn{3}{|c|}{ Total } & 27 & $100 \%$ \\
\hline
\end{tabular}

(Arikunto, 2009:245)

Based on the table above, there were 11 students got score 80-100 categorized to get very good score and there were 10 students got score 66-79 categorized to get good score, and there were 6 students got score 56-65 categorized to get enoughscore. Thus, the majority of the students in experimental class were classified into Very Good categorized.

2. Data Presentation of Students' Reading 


\section{Comprehension Who without Taught by vocabulary journal Strategy}

The data of students' reading comprehension in narrative text taught by using conventional strategy were obtained from pre-test and posttest of VIII 2 class as control class. The data can be seen from the table below:

Table IV.2

Pre-test and Post-test Score of Control Class

\begin{tabular}{|c|l|c|c|c|c|}
\hline \multirow{2}{*}{ No. } & \multirow{2}{*}{ Students } & \multicolumn{3}{|c|}{ Control Class } & \\
\cline { 3 - 6 } & & Pre-Test & Categories & Post-Test & Categories \\
\hline $\mathbf{1}$ & Student 1 & 55 & Less & 55 & Less \\
\hline $\mathbf{2}$ & Student 2 & 45 & Less & 60 & Enough \\
\hline $\mathbf{3}$ & Student 3 & 50 & Less & 55 & Less \\
\hline $\mathbf{4}$ & Student 4 & 50 & Good & 65 & Enough \\
\hline $\mathbf{5}$ & Student 5 & 60 & Enough & 60 & Enough \\
\hline $\mathbf{6}$ & Student 6 & 40 & Less & 45 & Less \\
\hline $\mathbf{7}$ & Student 7 & 55 & Less & 60 & Enough \\
\hline $\mathbf{8}$ & Student 8 & 60 & Enough & 65 & Enough \\
\hline $\mathbf{9}$ & Student 9 & 45 & Less & 50 & Less \\
\hline $\mathbf{1 0}$ & Student 10 & 50 & Less & 55 & Less \\
\hline $\mathbf{1 1}$ & Student 11 & 65 & Enough & 70 & Good \\
\hline $\mathbf{1 2}$ & Student 12 & 35 & Fail & 50 & Less \\
\hline $\mathbf{1 3}$ & Student 13 & 45 & Less & 55 & Less \\
\hline $\mathbf{1 4}$ & Student 14 & 50 & Less & 60 & Enough \\
\hline $\mathbf{1 5}$ & Student 15 & 45 & Less & 55 & Less \\
\hline $\mathbf{1 6}$ & Student 16 & 45 & Less & 50 & Less \\
\hline $\mathbf{1 7}$ & Student 17 & 50 & Less & 55 & Less \\
\hline $\mathbf{1 8}$ & Student 18 & 65 & Enough & 70 & Good \\
\hline $\mathbf{1 9}$ & Student 19 & 65 & Enough & 75 & Good \\
\hline $\mathbf{2 0}$ & Student 20 & 45 & less & 50 & Less \\
\hline $\mathbf{2 1}$ & Student 21 & 55 & Less & 75 & Good \\
\hline $\mathbf{2 2}$ & Student 22 & 65 & Enough & 70 & Good \\
\hline $\mathbf{2 3}$ & Student 23 & 60 & Enough & 65 & Enough \\
\hline $\mathbf{2 4}$ & Student 24 & 60 & Enough & 65 & Enough \\
\hline $\mathbf{2 5}$ & Student 25 & 55 & Less & 75 & good \\
\hline $\mathbf{2 6}$ & Student 26 & 70 & Good & 80 & Very good \\
\hline $\mathbf{2 7}$ & Student 27 & 50 & Less & 55 & Less \\
\hline & Total & & 1435 & & 1645 \\
\hline & & & & & \\
\hline
\end{tabular}




\section{a. Pre-Test Score of Control Class}

Table IV.3

The Distribution of Frequency of Students' Pre-Test Scores of Control Class

\begin{tabular}{|c|c|c|c|c|c|}
\hline \multicolumn{6}{|c|}{ Precontrol } \\
\hline & & Frequency & Percent & Valid Percent & Cumulative Percent \\
\hline \multirow[t]{9}{*}{ Valid } & 35 & 1 & 3.7 & 3.7 & 3.7 \\
\hline & 40 & 1 & 3.7 & 3.7 & 7.4 \\
\hline & 45 & 6 & 22.2 & 22.2 & 29.6 \\
\hline & 50 & 6 & 22.2 & 22.2 & 51.9 \\
\hline & 55 & 4 & 14.8 & 14.8 & 66.7 \\
\hline & 60 & 4 & 14.8 & 14.8 & 81.5 \\
\hline & 65 & 4 & 14.8 & 14.8 & 96.3 \\
\hline & 70 & 1 & 3.7 & 3.7 & 100.0 \\
\hline & Total & 27 & 100.0 & 100.0 & \\
\hline
\end{tabular}

Referring to the table above, the total number of students were 27 students. It showed that there was 1 student who got score $35(3.7 \%), 1$ student who got $40(3.7 \%)$, 6students who got $45(22.2 \%), 6$ students who got $50(22.2 \%), 4$ students who got $55(14.8 \%)$, 4students who got $60(14.8 \%)$, 4 students who got $65(14.8 \%)$, and 1 student who got $70(3.7 \%)$

\section{b. Post-Test Score of Control Class}

Table IV.4

The Distribution of Frequency of Students' Post-Test Scores of Control Class

\begin{tabular}{|c|c|c|c|c|c|}
\hline & & Frequency & Percent & Valid Percent & $\begin{array}{l}\text { Cumulative } \\
\text { Percent }\end{array}$ \\
\hline \multirow[t]{9}{*}{ Valid } & 45 & 1 & 3.7 & 3.7 & 3.7 \\
\hline & 50 & 4 & 14.8 & 14.8 & 18.5 \\
\hline & 55 & 7 & 25.9 & 25.9 & 44.4 \\
\hline & 60 & 4 & 14.8 & 14.8 & 59.3 \\
\hline & 65 & 4 & 14.8 & 14.8 & 74.1 \\
\hline & 70 & 3 & 11.1 & 11.1 & 85.2 \\
\hline & 75 & 3 & 11.1 & 11.1 & 96.3 \\
\hline & 80 & 1 & 3.7 & 3.7 & 100.0 \\
\hline & Total & 27 & 100.0 & 100.0 & \\
\hline
\end{tabular}

Referring to the table above, from the total number of students were 27 students. It showed that there was 1 student who got score 45 (3.7\%), 4 students who got 50 (14.8\%), 7 students who got55 (25.9\%), 4 students who got $60(14.8 \%), 4$ students who got $65(14.8 \%), 3$ students who got $70(11.1 \%), 3$ students who got $75(11.1 \%)$, and 1 student who got $80(3.7 \%)$ 
Table IV. 5

The Classification of Students' Score

\begin{tabular}{|c|c|c|c|c|}
\hline $\mathrm{NO}$ & Score & Categories & Frequency & Percentage \\
\hline 1 & $80-100$ & Very good & 1 & $5 \%$ \\
\hline 2 & $66-79$ & Good & 6 & $18 \%$ \\
\hline 3 & $56-65$ & Enough & 8 & $27 \%$ \\
\hline 4 & $40-55$ & Less & 12 & $50 \%$ \\
\hline 5 & $30-39$ & Fail & - & - \\
\hline \multicolumn{3}{|c|}{ Total } & 27 & $100 \%$ \\
\hline
\end{tabular}

Based on the table above, there was 1 student got score $80-100$ and categorized to get very good score and there were 6 students got score 66-79 categorized to get good score, and there were 8 students got score 56-65 categorized to get enoughscore, and there were 12 students got score 56-65 categorized to get less score. Thus, the majority of the students in control class were classified into less categorized

\section{Normality Homogeneity of the Test} In order to know whether the data used parametric or non-parametric analysis, the writer previously needed to apply normality analysis by using Kolmogorov Sminov method in SPSS 16.0 version which was described as follows:

Table IV.6

The Normality of the Test

Tests of Normality

\begin{tabular}{|l|r|r|r|r|r|r|}
\hline & \multicolumn{4}{|c|}{ Kolmogorov-Smirnov $^{\mathrm{a}}$} & \multicolumn{3}{c|}{ Shapiro-Wilk } \\
\cline { 2 - 7 } & Statistic & \multicolumn{1}{c|}{ Df } & \multicolumn{1}{c|}{ Sig. } & Statistic & \multicolumn{1}{c|}{ df } & \multicolumn{1}{c|}{ Sig. } \\
\hline Postexp & .153 & 27 & .105 & .898 & 27 & .012 \\
Postcont & .160 & 27 & .075 & .941 & 27 & .126 \\
\hline
\end{tabular}

a. Lilliefors Significance Correction

If the probability $>0.05$

$\mathrm{H}_{\mathrm{o}}$ is accepted

If the probability $<0.05$

$\mathrm{H}_{\mathrm{o}}$ is rejected

Based on the table above, the test of normality of post-test experimental class shows: sig. was $0.105>0.05$, it means that Ho was accepted. The test of normality of post-test control shows: sig. was $0.75>0.05$, meaning that Ho was accepted. In other words, the both data were normally distributed.

Then, the writer also had to find the homogeneity of the test. It canbe seen in the table below: 
Table IV.7

Homogeneity of the Test

Test of Homogeneity of Variance

\begin{tabular}{|ll|r|r|r|r|}
\hline & Levene Statistic & df1 & df2 & \multicolumn{1}{c|}{ Sig. } \\
\hline Post $\quad$ Based on Mean & .090 & 1 & 52 & .765 \\
& & .126 & 1 & 52 & .725 \\
& Based on Median & .126 & 1 & 50.583 & .725 \\
Based on Median and & .106 & 1 & 52 & .746 \\
\hline with adjusted df & & & 1 & \\
Based on trimmed mean & & &
\end{tabular}

Based on the table above, it can be seen that sig. in Based on trimmed mean is $0.746>0.05(5 \%)$. Thus, the writer concluded that the test was homogeneous variance.
2. The Difference of Students' Reading Comprehension between Experimental and Control Group

The data analysis of students' reading comprehension of experimental class and control class was based on mean and standard deviation of both classes. The result canbe seen in the table below:

Table IV.9

The Mean and Standard Deviation of Pre-Test and Post of Experiment and Control Class

\begin{tabular}{|ll|r|r|r|r|}
\hline \multicolumn{7}{|c|}{ Group Statistics } \\
\hline \multirow{2}{*}{ Post } & group & $\mathrm{N}$ & Mean & Std. Deviation & Std. Error Mean \\
& experiment & 27 & 75.3704 & 10.37062 & 1.99583 \\
& control & 27 & 60.9259 & 9.30643 & 1.79102 \\
\hline
\end{tabular}

Based on the table above, it could be seen that the total number of the students from experimental group was 27 and control group was 27 , the mean of experimental group was 75.37 , and mean score of control group was60.92. Standard deviation from experimental group was10.37, while standard deviation from control group was 9.30. Standard error mean experimental group was1.99, and control group was 1.79.

Next, the writer would like to explain independent sample test, it can be described in the table belows: 
Table IV.10

Independent Sample T-Test

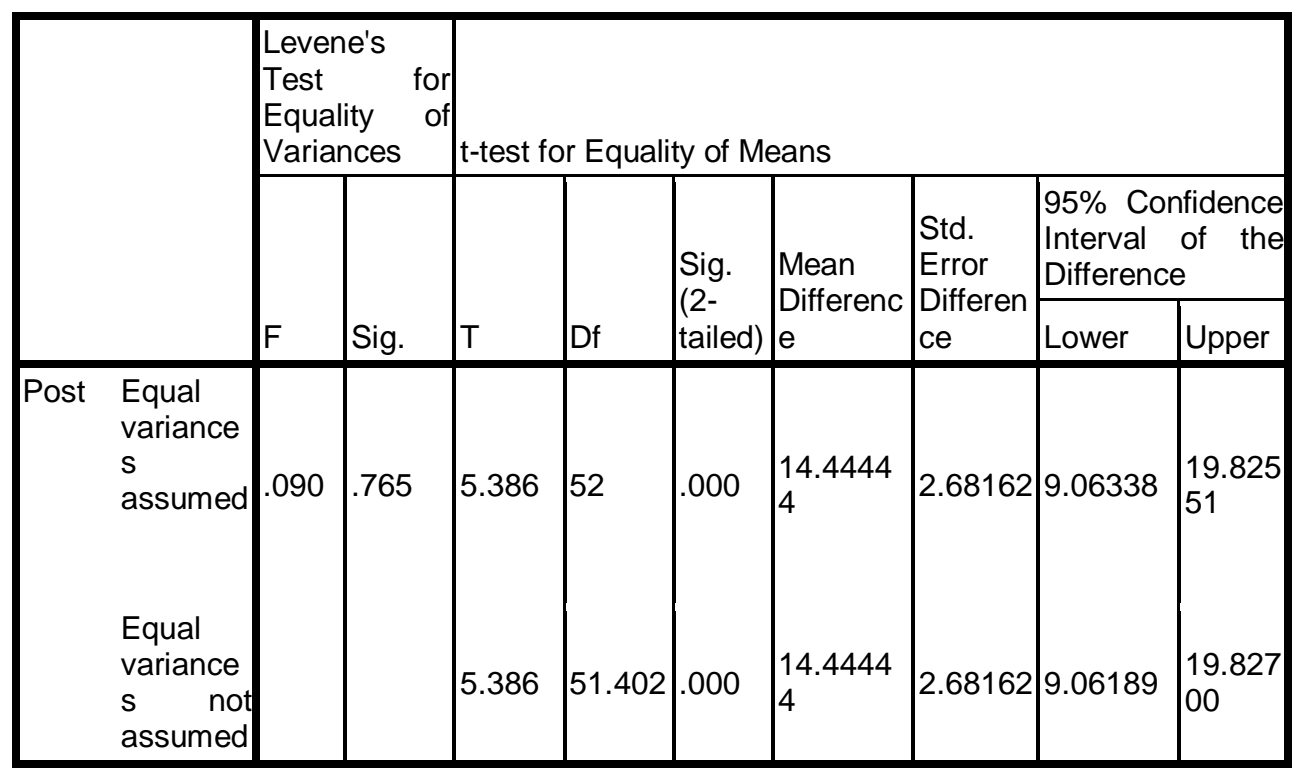

From the table of independent sample test above showed that the t-test result was 5.386, df was 52, sig. (2-tailed) was 0.000 , mean difference was 14,44 , standard error was 2.68162, lower difference interval was 9.06, and upper difference interval was 19.82 .

If $\boldsymbol{t}_{\boldsymbol{o}}(\mathrm{t}$-observation) was 5.386 compared with $\boldsymbol{t}_{t}(\mathrm{t}$-table $)$ with df 52, the t-critic point was:

Significance $5 \%=2.03$

Significance $1 \%=2.72$

It can be seen that $\boldsymbol{t}_{\boldsymbol{o}}=$ 5.386 in significance level of 5\% and $1 \%(2.03<5.386>2.72)$. It means that $\mathrm{H}_{\mathrm{o}}$ was rejected and $\mathrm{H}_{\mathrm{a}}$ was accepted; or there is a significant effect of using Vocabulary Journal strategy on students' reading comprehension in narrative texts.

The result was teaching reading by using Vocabulary
Journal strategy was better than without using Vocabulary Journal strategy. It means, there is significant difference between the students taught and without taught by using Vocabulary Journal strategy on students' reading comprehension in narrative texts of the eighth grade at Junior High School 1 Cerenti Kuantan Singingi Regency.

3. The Effect of Using Vocabulary Journal Strategy on Students' Reading Comprehension in Narrative Text

To identify the level of the effect of using Vocabulary Journal strategy on students' reading comprehension at Junior High School 1 Cerenti Kuantan Singingi Regency, it was calculated by using eta squared formula: 


$$
\begin{array}{ll}
\text { Eta Squared } & =\frac{\mathrm{t}^{2}}{\mathrm{t}^{2}+(\mathrm{n} 1+\mathrm{n} 2-2)} \\
\text { Eta Squared } & =\frac{5.386^{2}}{5.386^{2}+(27+27)-2} \\
\text { Eta Squared } & =\frac{29.008996}{29.008996+52} \\
\text { Eta Squared } & =\frac{29.008996}{81.008996} \\
\text { Eta Squared } & =0.358
\end{array}
$$

Based on the result above, it was clear that the effect size was 0.358. The guidelines (proposed by Cohen, 1988 in Pallant, 2005: 209) for interpreting this value are: 0.01 is small effect, 0.06 is moderate effect, and 0.14 is large effect. It means that the using Vocabulary Journal strategy had large effect on students' reading comprehension. Then, the interpretation of the effect size of difference was considered Large.

Then, to find out the percentage of coefficient effect $\left(\mathrm{K}_{\mathrm{p}}\right)$, it used the following formula:

$$
\begin{aligned}
& \mathrm{K}_{\mathrm{p}}=\mathrm{r}^{2} \times 100 \% \\
& \mathrm{~K}_{\mathrm{p}}=(0.358)^{2} \times 100 \% \\
& \mathrm{~K}_{\mathrm{p}}=0.128164 \times 100 \% \\
& \mathrm{~K}_{\mathrm{p}}=12.8164 \%
\end{aligned}
$$

From the result of the percentage of coefficient effect above, it can be seen that using vocabulary journal strategy just contributed $12.8164 \%$ for students' reading comprehension.

Therefore, the writer concluded that there is significant effect of using vocabulary journal strategy on students' reading comprehension in narrative texts at Junior High School 1 Cerenti Kuantan Singingi Regency.

4. The Observation Data of using Vocabulary Journal Strategy

In order to present the data about the use of Vocabulary Journal Strategy on experimental group, the writer was able to collect one observation. Actually, the writer taught eight times in the sample group but the teacher who observe could not observe seven meeting because of her responsibility to the school. So, the writer could not collect the observation lists completely. To make it clear the data presentation can be seen as follows:

The following table describes about the frequency of each item that becomes indicators of using Vocabulary Journal Strategy on experimental group 
Table IV. 11

The Observation Data on Experimental Group

\begin{tabular}{|c|l|c|c|}
\hline No. & \multicolumn{1}{|c|}{ Option } & Yes & No \\
\cline { 3 - 4 } & & \multicolumn{1}{|c|}{ The Dimension of Contrast } \\
\hline 1 & $\begin{array}{l}\text { The teacher introduces Vocabulary Journals to } \\
\text { students. }\end{array}$ & $\mathbf{V}$ & - \\
\hline 2 & $\begin{array}{l}\text { The teacher Demonstrate how to select words from a } \\
\text { reading Conduct a read-aloud to show the students } \\
\text { which words might be selected for their Vocabulary } \\
\text { Journals. }\end{array}$ & $\mathbf{V}$ & \\
\hline 3 & $\begin{array}{l}\text { The teacher Use a think-aloud to model how to } \\
\text { construct meanings from words. }\end{array}$ & $\mathbf{V}$ \\
\hline 4 & $\begin{array}{l}\text { Record ideas that have been used to explore the } \\
\text { meaning of the word. Display different techniques } \\
\text { that were used to represent word meanings and } \\
\text { relationships. }\end{array}$ & $\mathbf{V}$ & - \\
\hline 5 & $\begin{array}{l}\text { The teacher encourages students' systematic use and } \\
\text { sharing of Vocabulary Journals. }\end{array}$ & $\mathbf{V}$ & - \\
\hline 6 & $\begin{array}{l}\text { Next, the teacher Encourages students to use their } \\
\text { Vocabulary Journals as a resource. }\end{array}$ & $\mathbf{V}$ & - \\
\hline TOT & $\mathbf{1 0 0 \%}$ & \\
\hline
\end{tabular}

Based on the table above shows that in the classroom activity, the writer introduced Vocabulary Journals to students, and Demonstrated how to select words from a reading by Conducting a read-aloud to show the students which words might be selected for their Vocabulary Journals, then, Use a think-aloud to model how to construct meanings from words, and Record ideas that have been used to explore the meaning of the word. Display different techniques used to represent word meanings and relationships, encourages students' systematic use and sharing of Vocabulary Journals, and the last Encourages students to use their Vocabulary Journals as a resource.

The table above shows that the result of observation of the use of Vocabulary Journals Strategy on experimental group acquired the answer "yes" is 6, and the answer "no" is 0 . So, it can be concluded that the use of Vocabulary Journals is running well or it can be categorized very good.

During the treatment, English teacher did observation based on the indicators of variable $\mathrm{X}$ (Buzz Group Technique). The writer provided the observation checklist as follows: 
TABLE IV.III

Analyzed Observation List

\begin{tabular}{|c|l|c|c|c|c|c|c|c|c|}
\hline \multirow{2}{*}{ No } & \multirow{2}{*}{ Meetings } & \multicolumn{7}{|c|}{ Indicators of Variable X } \\
\cline { 3 - 11 } & 1 & 2 & 3 & 4 & 5 & 6 & 7 & 8 \\
\hline 1 & First meeting & $\sqrt{ }$ & $\sqrt{ }$ & $\sqrt{ }$ & $\sqrt{ }$ & $\sqrt{ }$ & $\sqrt{ }$ & - & - \\
\hline 2 & $\begin{array}{l}\text { Second } \\
\text { meeting }\end{array}$ & $\sqrt{ }$ & $\sqrt{ }$ & $\sqrt{ }$ & $\sqrt{ }$ & $\sqrt{ }$ & $\sqrt{ }$ & - & - \\
\hline 3 & Third meeting & $\sqrt{ }$ & $\sqrt{ }$ & $\sqrt{ }$ & $\sqrt{ }$ & $\sqrt{ }$ & $\sqrt{ }$ & $\sqrt{ }$ & - \\
\hline 4 & $\begin{array}{l}\text { Fourth } \\
\text { meeting }\end{array}$ & $\sqrt{ }$ & $\sqrt{ }$ & $\sqrt{ }$ & $\sqrt{ }$ & $\sqrt{ }$ & $\sqrt{ }$ & $\sqrt{ }$ & - \\
\hline 5 & Fifth meeting & $\sqrt{ }$ & $\sqrt{ }$ & $\sqrt{ }$ & $\sqrt{ }$ & $\sqrt{ }$ & $\sqrt{ }$ & $\sqrt{ }$ & $\sqrt{ }$ \\
\hline 6 & Sixth meeting & $\sqrt{ }$ & $\sqrt{ }$ & $\sqrt{ }$ & $\sqrt{ }$ & $\sqrt{ }$ & $\sqrt{ }$ & $\sqrt{ }$ & $\sqrt{ }$ \\
\hline & Total & 6 & 6 & 6 & 6 & 6 & 6 & 4 & 2 \\
\hline
\end{tabular}

From table IV.III it was found that in first meeting only 6 indicators that have done, second, third and fourth meeting there was 7 indicators that have done, and in fifth and sixth meeting all of indicators that have done.

According to Sudjiono (2010: 43), the following formula that can be used to get percentage of the observation list. So the writer used the formula:

$$
P=\frac{F}{N} x 100 \%
$$

Where:

$$
\begin{array}{lll}
\mathrm{P} & : & \text { Percentage } \\
\mathrm{F} & : & \text { Frequency of the score } \\
\mathrm{N} & : & \text { Number of case }
\end{array}
$$$$
\text { Percentage of 'Yes' }=\frac{42}{48} \times 100 \%
$$$$
=87,5 \%
$$

$$
\text { Percentage of }{ }^{\prime} N o^{\prime}=\frac{6}{48} \times 100 \%
$$$$
=12,5 \%
$$

According to Arikunto (2011:245) the category of the observation list can be seen below:
a. $76-100 \%=$ Very good
b. $56-75 \%$
$=$ Enough
c. $40-55 \%$
$=$ Less

d. Less than $40 \%=$ Bad

The table IV.III shows that the result of observation of the effect in experimental class. The result of observation for answer 'Yes' was $87,5 \%$, and it can be categorized in the level of very good, while for answer 'No' was $12,5 \%$, it can be categorized into the level bad.

\section{References}

Arikunto, Suharsimi. 2009. Dasardasar Evaluasi Pendidikan. Jakarta: Bumi Aksara.

Brown, H. Douglas. 2003. Language Assessment Principles and Classroom Practice. San Fransisco: San Fransisco State University.

BSNP (Badan Standar Nasional Pendidikan). 2006. Standar Isi Untuk Satuan Pendidikan: Standar Kompetensi dan Kompetensi Dasar SMP/MTs. Jakarta. Unpublished.

Bone, B. 2000. Lessons from a Vocabulary Journal.Voices From the Middle, 
Cohen et. Al. 2007. Research Method in Education. New York: Routledge.

Cresswell, John W. 2008. Educational Research: Planning, Conducting and Evaluating Quantitative and Qualitative Research (New Jersey: Pearson Education)

Dorn, Linda J. Carla Soffos. 2015. Teaching for Deep Comprehension. Portland: Stenhouse Publisher.

Firdaus, 2013.The Effect of Using Keeping Journals Technique towards Ability in Writing Narrative Text at the Second Year Students of SMAN 1 Tapung of Kampar Regency.Unpublished

Research.Pekanbaru:

UnivarsitasNegri Sultan Syarif Kasim Riau.

Gay, L,R, Peter Airasian, 2000. Educational Research Competencies for Analysis and Application Sixth Edition (New Jersey: Pearson Education).

Hartono. 2004. Statistika untuk Pendidikan. Yogyakarta: Pustaka Pelajar.

Hasibuan, Kalayo., and M. Fauzan Ansyari. 2007. TeachingEnglish Foreign Language (TEFL). Pekanbaru: Alaf Riau Graha UNRI Press.

Hughes, Arthur. 2003. Testing for Language Teacher Second Edition. United Kingdom: Cambridge University Press.

June Preszler, 1925. On Target: Strategies to Build Student
Vocabularies. Rapid City: Plaza Boulevard.

Klinger, Janette K..Sharon Vaughn and Alison Boardman. 2007. Teaching Reading Comprehension to Students with Learning Difficulties. London: The Guilford Press.

Manser, Martin H. 1995.Oxford Learner's Pocket Dictionary. New York: Oxford University Press.

Marzano, Robert J., and Debra J. Pickering.2005 .Building Academic Vocabulary: Teacher's Manual. Alexandria, VA: ASCD.

Mintzberg, Henry. 1994. The Rise and Fall of Strategic Planning: Reconceiving Roles for Planning, Plans, Planner. New York: The Free Press.

Mukarto et al. 2007. EOS: English on Sky 2 for Junior High School Students Year VIII. Jakarta: Erlangga.

Oxpord, Rebecca L. 1989. Language Learning Strategies.Boston: HEINLE \& HEINLE PUBLISHER.

Pallant, Julie. 2005. SPSS Survival Manual: A Step by Step Guide to Data Analysis Using SPSS for Windows (Version 12). Australia: Allen and Unwin.

Patel, M.F, and Praveen M. Jain. 2008. English Language Tecahing (Methods, Tools, and Techniques). Jaipur: Sunrise Publisher and Distributors. 
Patrisia, A. Antonacci, Chaterine M. O'Callaghan, 2012. Promoting Literacy Development. New York: SAGE Publication..

Richards,J.C and Richard Schmidt. 2002. Longman Dictionarry of Language Teaching and Applied Linguistic. Third Edition. New York: Pearson Education.

Richards, J.C., John Platt, Heidi Platt. 1992. Longman Dictionarry of Language Teaching and Applied Linguistic. New York: Longman.

Sharon, Vough, and Silvia 2004.Research-Based Method of Reading Instruction; Grades-3.Virginia: Association for Supervision and Cuericulum Development.

Snow, Catherine E. 2002: Reading for Understanding toward an $R \&$ $D$ in Reading comprehension. Santa Monica: RAND.

Sudarwati, M Th and Eudia Grace. 2007. Look Ahead: An English Course for Senior High School Students Year $X$. Jakarta: Erlangga.

Sutiyah, 2013.The Effect of Using Double-Entry Journals Technique toward Reading Comprehension of the Second Year Students at Senior High School 3 Kuala Merbau of Meranti Island Regency.UnpublishedResearch. Pekanbaru: universitasNegri Sultan SyarifKasim Riau.
Syafii S. 2013. From Paragraphs to a Research Report: A Writing of English for Academic purposes. Pekanbaru: Suska Pres.

Syafii, M, et al. 2007. A Writing English for Academic Purposes. Pekanbaru: LBSI, 2007.

Syafi;I S., M. M. Fauzan Ansyari, and Jonri Kasdi. 2011. The Effective paragraph Developments: The Process of Writing for Classroom Settings. Pekanbaru: Lembaga Bimbingan BelajarS yaf Intensive (LBSI).

Syahputra, Idham. 2014. Teaching Receptive Skill Theory and Practice. Pekanbaru: Suska Press.

Tankerlay,Karen. 2003. Threads of Reading: Strategies For Literacy Development. United state of America: ASCD. 